А.В. Лисиця, І.М. Тіхонов, В.В. Василенко, В.О. Явтушенко

Харківський національний університет Повітряних Сил ім. І. Кожедуба, Харків

\title{
АНАЛІЗ МЕХАНІЗМІВ УРАЖЕННЯ ЦІЛІ, ЯКА МАЄ ЗАСОБИ ІНДИВІДУАЛЬНОГО БРОНЬОВАНОГО ЗАХИСТУ ЗІ СТРІЛЕЦЬКОЇ ЗБРОЇ НА ОСНОВІ ЕНЕРГЕТИЧНОГО ПОТЕНЦІАЛУ ТА СИЛИ УДАРУ КУЛІ 5,45 ММ, 5,56 Мм, 7,62 ММ
}

У статті проведено аналіз захисних властивостей засобів індивідуального броньованого захисту. Досліджується зміна захисного ефекту в залежності від типу патрону на відстані стрільби в межах прямого пострілу. Дано огляд залежності кінетичної енергії та середньої сили удару кулі від відстані стрільби, зроблено висновок, щзодо впливу пробивної, клиноподібної, гідродинамічної та забивної спроможності куль різних калібрів. Розглянуто актуальність ураження захищених иілей противника в умовах ведення бойових дій. Досліджено взаємозалежності енергетичних та силових характеристик типових куль вітчизняних та зарубіжнх виробників на відстані стрільби зі стрілецької зброї, в межах прямого пострілу, з метою пошуку оптимальної ефективної відстані стрільби по захищених иілях. Оцінено відомі механізми ураження цілі та визначено на якій відстані стрільби домінує той чи інший механізм ураження. Запропоновано для практичного використання класифікацію заброньованого контузійного травмування, яке має місце при певній силі удару, для визначення мінімального часу на відновлення боєздатності ураженої иілі. Результати роботи можуть бути використані при формуванні вимог до правил стрільби по захищених ијілях, а також при навчанні у стрільбі зі стрілецької зброї.

Ключові слова: засіб індивідуального броньованого захисту, прямий постріл, кінетична енергія кулі, середня сила удару кулі, захисний коефіцієнт иฺілі, механізм ураження иүілі.

\section{Вступ}

Постановка проблеми. Сьогоденний бойовий досвід вказує, що бронежилет і захисний шолом є невід’ємною частиною бойової екіпіровки військовослужбовця, важливим психофізичним фактором його бойової активності, сміливості та рішучості при виконанні завдань, фактором збереження життя й здоров'я. Через те, що у стрільця і його цілі, у наявності $\epsilon$ засоби індивідуального броньованого захисту (далі - ІБЗ) безумовно змінюється ефективність стрільби зі стрілецької зброї, за рахунок зменшення уразливої площі цілі. При тому засоби ІБЗ здійснюють вплив на ергономічні можливості стрільця, що можуть бути причиною збільшення розсіювання при стрільбі та підвищують витрату часу на виправлення наведення зброї в ціль після пострілу. А також і захисні властивості цілі, що є у засобі ІБЗ, можуть змінюватись в залежності від умов їх використання (класу захисної структури, відстані стрільби, калібру боєприпасів і т.ін.). У цьому випадку виникає завдання щодо визначення оптимальної відстані ефективної стрільби зі стрілецької зброї при якій може бути уражена або втратить боєздатність захищена ціль.

Вказане завдання $є$ актуальним та пов'язане 3 необхідністю знищення цілі, яка знаходяться на відстані стрільби в межах прямого пострілу та захищена засобами ІБЗ.

На даний час розв'язання вказаного завдання проводиться лише за рахунок оснащення стрілецької зброї новітніми прицільними пристосуваннями (коліматорними та тепловізійними прицілами), чим пояснюється відсутність напрацювань у напрямку оцінювання механізмів ураження захищеної цілі на відстані стрільби, в межах прямого пострілу, маючи за основу енергетичні та силові характеристики куль різних калібрів з метою завдання втрати боєздатності захищеної цілі.

Для цього пропонується визначити енергетичний потенціал засобу ІБЗ відповідного класу, енергетичний та силовий потенціал куль різних калібрів, в межах стрільби на відстані прямого пострілу. Потім, порівнюючи енергетичні характеристики засобу ІБЗ і куль, визначити відстані стрільби, при яких матимуть місце пробивний, клиноподібний, гідродинамічний (розривний) або забивний (контузійний) механізм ураження цілі. На основі оцінювання та порівняння між собою внесків усіх механізмів ураження цілі визначити, яким чином буде змінюватись захисний ефект цілі, що знаходиться у засобі ІБЗ в залежності від відстані стрільби та типу боєприпасів до стрілецької зброї.

Аналіз останніх досліджень і публікацій. Попередній науковий досвід зазначений, у наукових роботах [1-4], розглядає зростання вимог щодо перспектив розвитку, вимог до якості матеріалів, класів захисту та тактико-технічних характеристик, засобів ІБЗ і визначає головні напрямки розвитку та вимоги 
до сучасних засобів захисту:

- створення бронежилетів високого класу захисту (4-6) з відносно невеликою вагою (до 14 кг) та максимальною площею захисту;

- класи захисту бронежилету повинні враховувати велику різновидність боєприпасів стрілецької зброї;

- тактико-технічні характеристики бронежилету повинні дотримувати баланс між рухомістю людини та їі захищеністю.

У роботі [5], описано методику оцінювання вбивчої дії звичайних куль різних калібрів, яка дозволяє врахувати як змінюватиметься вбивча дія кулі по цілі в залежності від відстані стрільби, проте цілі, які екіпіровані засобами ІБЗ не розглядалися.

У дослідженні [6-7], розроблено методику зниження енергетичних характеристик уражаючого елементу після відбиття від перешкоди. Розглянуто можливість зниження швидкості руху уражаючого елементу після відбиття від поверхні перешкоди до прийнятного рівня за рахунок змінювання механічних властивостей його конструкції. Але не визначено, яку силу удару матиме уражаючий елемент після відбиття від перешкоди на певній відстані стрільби і як впливатиме іiі значення на забезпечення безпеки застосування стрілецької зброї. У зв'язку з цим виникає потреба в проведенні дослідження щодо існуючих механізмів ураження цілей визначення їх впливу на захисний ефект цілі на відстані стрільби в межах прямого пострілу, визначення ефективних відстаней для стрільби по захищених цілях.

Мета статті - оцінювання механізмів вогневого ураження захищених цілей на відстані прямого пострілу за рахунок енергетичного потенціалу та ударної дії кулі, різних типів боєприпасів вітчизняних та зарубіжних виробників.

\section{Виклад основного матеріалу}

3 прийнятих вимог до конструкцій ІБЗ [8] відомо, що його захисною структурою $\epsilon$ сукупність захисних елементів, які при одиночному (індивідуальному) використанні здатні поглинати та розсіювати енергію засобів ураження, при взаємодії з іншими конструктивними елементами цього засобу захисту амортизувати та зменшувати динамічні навантаження на тіло людини. Динамічним навантаженням $є$ динамічний вплив (удар) кулі - обмежений за часом $(0,01$ с) на тіло людини яка перебуває у засобі ІБЗ.

Класом захисної структури є показник стійкості захисної структури засобу ІБЗ щодо впливу енергії засобу ураження вогнепальної стрілецької зброї.

Засобом ураження вогнепальної зброї $є-$ куля, яка викидається енергією порохових газів 3 каналу ствола зброї, рухається з початковою швидкістю по траєкторії до точки зустрічі з ціллю. На сьогодні виникають актуальні завдання щодо визначення енергетичного потенціалу засобу ІБЗ, порівняння його значення зі значеннями енергетичного потенціалу засобу ураження та визначення відстаней стрільби при яких можливе пробиття засобу ІБЗ, визначення значень динамічного навантаження яке отримує людина при влученні кулі в захисний елемент засобу ІБЗ та можливих наслідків для іiі життя та здоров'я. В проведеному дослідженні [9] стверджується, що єдиної у світі стандартизації та класифікації бронежилетів не існує. Це пов'язано $з$ тим, що при класифікації засобів захисту різними країнами застосувались характеристики тих патронів, які використовуються в збройних силах цих країн. Розробники засобів ІБЗ адаптують їх під більш найпоширеніші типи боєприпасів.

В (табл. 1) приведемо класи захисних структур засобів ІБЗ збройних сил Російської Федерації (далі - ЗС РФ) та характеристики боєприпасів, від яких здійснюється захист.

Таблиця 1

Класи захисних структур ГОСТ Р 50744 - 95 (РФ)

\begin{tabular}{|c|c|c|c|}
\hline Клас & Тип патрону & $\begin{array}{l}\text { Вага } \\
\text { кулі } \\
(г)\end{array}$ & $\begin{array}{l}\text { Швидкість } \\
\text { кулі (м/с) }\end{array}$ \\
\hline Бр1 & $\begin{array}{c}9 \times 18 \text { мм пістолет- } \\
\text { ний патрон } 3 \text { кулею } \\
\text { Пст. інд. 57-Н- } \\
181 \mathrm{C}\end{array}$ & 5,9 & $335 \pm 10$ \\
\hline Бр2 & $\begin{array}{c}9 \times 21 \text { мм патрон з } \\
\text { кулею П. інд. 7Н28 }\end{array}$ & 7,93 & $390 \pm 10$ \\
\hline Бр3 & $\begin{array}{c}9 \times 19 \text { мм патрон } 3 \\
\text { кулею Пст. інд. } \\
7 \text { Н21 }\end{array}$ & 5,2 & $455 \pm 10$ \\
\hline Бр4 & $\begin{array}{c}\text { 5,45×39 мм патрон } \\
\text { з кулею ПП. інд. } \\
7 \text { Н10 } \\
\text { 7,62×39 мм патрон } \\
\text { з кулею ПС. інд. } \\
\text { 57-Н-231 }\end{array}$ & $\begin{array}{l}3,5 \\
7,9\end{array}$ & $\begin{array}{l}895 \pm 15 \\
720 \pm 15\end{array}$ \\
\hline Бр5 & $\begin{array}{c}\text { 7,62×54 мм патрон } \\
\text { з кулею ПП. інд. } \\
7 \text { Н13 } \\
\text { 7,62×54 мм патрон } \\
\text { з кулею Б32. інд. } \\
\text { 7Н13 }\end{array}$ & $\begin{array}{l}9,4 \\
10,4\end{array}$ & $\begin{array}{l}830 \pm 15 \\
810 \pm 15\end{array}$ \\
\hline Бр6 & $\begin{array}{c}12,7 \times 108 \text { мм па- } \\
\text { трон } 3 \text { кулею Б32. } \\
\text { інд. 57-Б3-542 }\end{array}$ & 48,2 & $830 \pm 20$ \\
\hline
\end{tabular}

Джерело: [8, С. 4].

Оскільки головним засобом ураження вогнепальної зброї є куля, визначимо значення іiї енергетичного потенціалу у точці зустрічі з ціллю. В залежності від величини кінетичної енергії та швидкості, 
визначимо на якій відстані стрільби домінує той чи інший механізм ураження цілі: пробивний, клиноподібний, гідродинамічний (розривний), або забивний (контузійний).

На основі прийнятої класифікації [10] визначено, що під пробивним механізмом ураження є дія кулі, що спостерігається при великій кінетичній енергії (тисячі Дж), яка, вибиваючи ділянку захисного елементу разом 3 нею утворює отвір у засобі ІБЗ та тканинах людини, різної форми, руйнує кістки, хрящі, внутрішні органи.

Клиноподібним механізмом ураження є дія кулі, що спостерігається при недостатній кінетичній енергії кулі (сотні Дж): тобто куля не пробиває захисний елемент та тканини людини, а стискує і розсовує розташовані попереду неї перешкоди (діє на зразок клину). Утворюючи тріщину в захисному елементі та щілиноподібний отвір в тканинах людини.

Гідродинамічним (розривним) механізмом ураження є дія кулі, що спостерігається при великій кінетичній енергії (сотні-тисячі Дж) та швидкості 700 м/с і більше, потрапляючи в органи, що містять рідину або органи з великим відсотком рідини (наповнений шлунок, серце, головний мозок, селезінку), під дією гідродинамічних сил відбуваються їх великі руйнування. Характерними ознаками механізму є незначне ушкодження органу в ділянці вхідного отвору і масивні руйнування в ділянці вихідної рани.

Забивним (контузійним) механізмом ураження $\epsilon$ дія кулі, яка спостерігається при їі малій кінетичній енергії, що поглинається захисною структурою засобу ІБЗ, має значення сили удару (десятки-сотні кгс) та заподіє заброньоване контузійне травмування (далі-ЗКТ) різного ступеня тяжкості для людини.

При розробці та проектуванні ІБЗ [8] визначено, що ЗКТ є пошкодження шкіряного покрову тіла i (або) внутрішніх органів людини від динамічних навантажень, які виникають при взаємодії засобу враження вогнепальної зброї з захисною структурою засобу ІБЗ при виконанні умови, що куля та уламки захисного елементу не проникають у тіло.

Для визначення енергетичного потенціалу засобів ІБЗ ЗС РФ від зазначених засобів ураження скористаємося вихідними значеннями наведеними в (табл. 1).

Кінетична енергія кулі у момент зустрічі 3 ціллю, визначається за формулою [11]:

$$
E_{\kappa}=\frac{m_{\kappa} \cdot V_{\kappa}^{2}}{2},
$$

де $E_{\kappa}-$ кінетична енергія кулі у точці зустрічі 3 ціллю (Дж);

$$
\begin{aligned}
& m_{\kappa}-\text { маса кулі (кг); } \\
& V_{\kappa}-\text { швидкість кулі у цілі (м/с). }
\end{aligned}
$$

Порогове значення величини кінетичної енергії, яке спроможний витримати захисний елемент бронежилета, можна ввести, як один 3 його показників в тактико-технічні характеристики, позначивши через $E_{б ж}$ (Дж).

Знайдені розрахункові значення порогового рівня кінетичної енергії $E_{\text {бж}}$, яку спроможний витримати захисний елемент бронежилета ЗС РФ, наведено в (табл. 2).

Для забезпечення пробивного механізму ураження захищеної цілі необхідно, щоб значення кінетичної енергії засобу ураження $E_{\kappa}$ перевищувало певне значення - величини кінетичної енергії захисного елементу бронежилета $E_{б ж}$.

Таблиця 2

Кінетична енергія кулі, яку здатний витримати захисний елемент бронежилета (ЗС РФ)

\begin{tabular}{|c|c|}
\hline \multicolumn{2}{|c|}{ РФ } \\
\hline Клас & $E_{\text {бж }}$ (Дж) \\
\hline Бр1 & 331,064 \\
\hline Бр2 & 603,077 \\
\hline Бр3 & 538,265 \\
\hline Бр4 & $1401,794-2047,68$ \\
\hline Бр5 & $3237,83-3411,72$ \\
\hline Бр6 & 14742,46 \\
\hline
\end{tabular}

Джерело: розроблено авторами за даними [8, С. 4].

У такому разі з отриманих значень величини

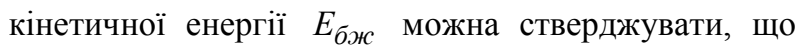
для гарантованого знищення захищеної цілі, засобом ІБЗ певного класу захисту, за рахунок дії пробивного механізму ураження, треба щоб кінетична енергія засобу ураження у точці зустрічі з цілю була більшою. Або відповідати величині енергії. на яку розрахований клас захисної структури засобу ІБЗ, щоб завдати ураження тілу людини, за рахунок клиноподібного, гідродинамічного або забивного механізмів ураження тобто повинна бути виконана умова:

$$
E_{\kappa} \geq E_{б \varkappa} .
$$

Знайдемо залежності кінетичної енергії кулі від відстані стрільби в межах прямого пострілу для типових боєприпасів вітчизняних та зарубіжних виробників. Проведемо оцінювання механізмів ураження цілі на відстані стрільби в межах прямого пострілу шляхом порівняння кінетичної енергії кулі з величиною порогового значення кінетичної енергії кулі, яку здатний витримати захисний елемент бронежилета певного класу захисту.

Під дальністю прямого пострілу балістика визначає, відстань в межах якої траєкторія польоту кулі на усьому своєму шляху не підіймається над 
лінією прицілювання вище за висоту цілі [5].

В (табл. 3) нами було приведено вихідні значення вагових, лінійних та балістичних характеристик типових боєприпасів вітчизняних та зарубіжних виробників. Для зазначених боєприпасів проведемо оцінювання механізмів вогневого ураження та визначимо їх вплив на зміну захисного ефекту засобу ІБЗ класу захисту (Бр1-5) при стрільбі зі стрілецької зброї на відстань стрільби в межах прямого пострілу.

Таблиця 3

Значення вагових, лінійних, балістичних характеристик, типових боєприпасів

\begin{tabular}{|c|c|c|c|c|c|c|}
\hline $\begin{array}{c}\text { Країна } \\
\text { виробник }\end{array}$ & Тип патрону & $\begin{array}{c}\text { Вага кулі } \\
\text { (кг) }\end{array}$ & $\begin{array}{c}\text { Калібр кулі } \\
\text { (м) }\end{array}$ & $\begin{array}{c}\text { Початкова } \\
\text { швидкість } \\
\text { кулі } V_{O}(\mathrm{~m} / \mathrm{c})\end{array}$ & $\begin{array}{c}\text { Дальність } \\
\text { прямого } \\
\text { пострілу по } \\
\text { ростовій фігу- } \\
\text { рі } X_{D}(\text { м }) \\
\end{array}$ & $\begin{array}{c}\text { Балістичний } \\
\text { коефіцієнт } \\
\text { кулі } C \\
\left(\mathrm{M}^{2} / \text { кг) }\right.\end{array}$ \\
\hline \multirow{2}{*}{ США } & $\begin{array}{c}7,62 \times 51 \\
7,62 \text { NATO }\end{array}$ & $9,7 \cdot 10^{-3}$ & $7,62 \cdot 10^{-6}$ & 850 & 703 & 2,933 \\
\hline & $\begin{array}{c}5,56 \times 45 \\
5,56 \text { NATO }\end{array}$ & $5 \cdot 10^{-3}$ & $5,56 \cdot 10^{-6}$ & 895 & 716 & 3,314 \\
\hline \multirow[b]{2}{*}{ Україна } & $\begin{array}{c}5,45 \times 39 \text { 7Н10 } \\
\text { "Форт221, АК74" }\end{array}$ & $3,62 \cdot 10^{-3}$ & $5,45 \cdot 10^{-6}$ & 900 & 707 & 3,684 \\
\hline & $\begin{array}{c}\text { 7,62×3, 7Н23 } \\
\text { “7,62 Малюк, } \\
\text { Вулкан”, АКМ }\end{array}$ & $8 \cdot 10^{-3}$ & $7,62 \cdot 10^{-6}$ & 730 & 582 & 4,224 \\
\hline
\end{tabular}

Джерело: [5, С. 51-62].

Для розрахунку значення кінетичної енергії кулі у точці зустрічі з ціллю $E_{\kappa}$ на дальності прямого пострілу, скористаємося формулою (3), яка визначає зв'язок між дальністю польоту кулі, початковою швидкістю кулі, швидкістю кулі у цілі, а також балістичним коефіцієнтом, що визначає гальмівну дію сили опору повітря на кулю [6,7].

$$
V_{D}=V_{0} \cdot e^{-k C D},
$$

де $V_{D}$ - швидкість кулі на відстані $D$ від дульного зрізу каналу ствола зброї (м/с);

$V_{0}$ - початкова швидкість кулі (м/с);

$k=3,29 \cdot 10^{-4}-$ коефіцієнт, що враховує дані закону опору повітря Сіаччі та стандартної атмосфери повітря 81 року (СА-81) (кг/м3);

$C$ - балістичний коефіцієнт кулі, ( $\left.{ }^{2} / \kappa г\right)$;

$D$ - відстань від дульного зрізу каналу ствола зброї (м).

У результаті розрахунків за формулами (1) та (3), отримали залежність (рис. 1), що зв'язує кінетичну енергію кулі з дальністю стрільби в межах прямого пострілу для боєприпасів, що розглядаються та порогові значення енергії на яку розрахований клас захисної структури засобу ІБЗ.

На основі перевірки виконання зазначеної раніше умови (2), визначимо відстані стрільби в межах яких домінують пробивний, клиноподібний, гідродинамічний (розривний) механізми ураження цілі.

Отже, найбільшим енергетичним потенціалом в межах відстані прямого пострілу володіє куля 7,62×51НАТО, значення їі кінетичної енергії на відстані стрільби до 50 метрів має 3240 Дж при шви-

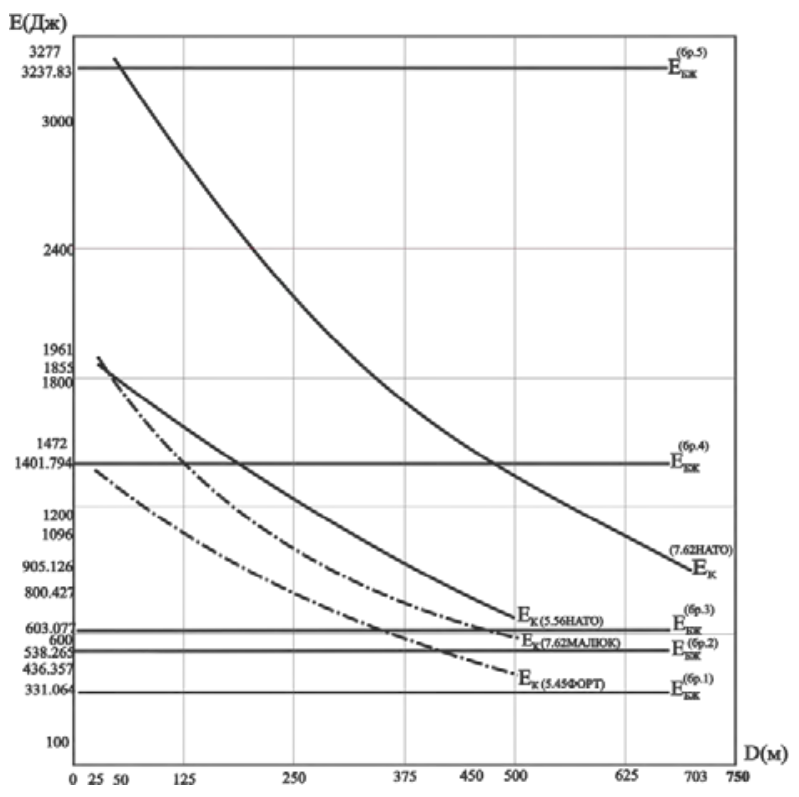

Рис. 1. Залежність кінетичної енергії кулі, на відстані стрільби в межах прямого пострілу та порогові значення енергії, на яку розрахований клас захисної структури засобу ІБЗ Джерело: розроблено авторами.

дкості 806,5 м/с, що може свідчити про іiі здатність знищити захищену ціль у засобі ІБЗ класу Бр.5 (РФ) за рахунок пробивного, клиноподібного, гідродинамічного (розривного), забивного (контузійного) механізмів ураження цілі. На відстані стрільби від 50 до 200 метрів, середнє значення ії кінетичної енергії становить 2706 Дж, а порогове значення швидкості, при якій спостерігається гідродинамічний ефект ураження, складає $701 \mathrm{~m} / \mathrm{c}$ на відстані стрільби 200 метрів. Це може свідчити про те, що вказана ціль у 
цих межах може бути знищена за рахунок клиноподібного, гідродинамічного (розривного), забивного (контузійного) механізмів. Відстань стрільби від 200 до 500 метрів за рахунок зменшення кінетичної енергії кулі, вказує на те, що ціль в ії межах може бути уражена шляхом отримання травмування різного ступеня тяжкості при забивному (контузійному) механізмі ураження. Серед вітчизняних боєприпасів, які обрані для дослідження, куля 5,45×39мм, має значення кінетичної енергії близько 1400 Дж та швидкість близько $880 \mathrm{~m} / \mathrm{c}$ на відстані стрільби 25 метрів, що дає нам вважати про ії здатність знищити захищену ціль засобом ІБЗ класу захисту Бр.4, на вказаній відстані, за рахунок клиноподібного, гідродинамічного (розривного), забивного (контузійного) механізмів ураження. На відстані стрільби 200 метрів, значення кінетичної енергії кулі 5,45×39мм, складає 902,169 Дж, а значення швидкості 706 м/с, що може свідчити про іiі здатність знищити вказану ціль за рахунок гідродинамічного (розривного), забивного (контузійного) механізмів ураження.

На відстані стрільби починаючи від 200 до 500 метрів домінуючим механізмом ураження цілі, що перебуває у засобі ІБЗ класу захисту Бр4, для вказаної кулі є забивний (контузійний).

Отримані залежності для куль різних калібрів зарубіжних та вітчизняних виробників вказують:

- енергетичний потенціал куль дозволяє задавати вогневе ураження захищеним цілям у засобах ІБЗ класу захисту Бр.4-1 за рахунок дії усіх вказаних механізмів ураження;

- відстані стрільби при яких мають місце пробивний, клиноподібний, гідродинамічний (розривний) механізми ураження спостерігаються до 200 метрів;

- на відстані стрільби починаючи від 200 до 500 метрів домінуючим механізмом ураження захищеної цілі засобом ІБЗ класу захисту Бр.4 слід вважати забивний (контузійний);

- для цілі, яка має засоби ІБЗ класу захисту Бр.5 та вище, при влучені засобу вогневого ураження в захисний елемент засобу ІБЗ, на всій відстані стрільби головним механізмом ураженням цілі слід вважати забивний (контузійний), що призводить втрату боєздатності за рахунок отримання динамічного навантаження на тіло людини.

У такому разі, визначимо якої ступені тяжкості травмування може отримати тіло людини, при влученні засобу ураження у захисний елемент засобу ІБ3, на основі визначення середньої сили удару кулі в точці зустрічі з ціллю. За прийнятої класифікації [8] визначено, що під втратою боєздатності цілі необхідно розуміти неспроможність нею, виконувати бойову задачу протягом певного мінімального часу на лікування. Для розрахунку значення середньої сили удару кулі у точці зустрічі з ціллю на відстані прямого пострілу, скористаємося формулою (4), яка визначає зв'язок між масою кулі, швидкістю руху кулі у цілі на початку удару, часом удару, а також коефіцієнтом відновлення що характеризує пружні властивості тіл які задіяні в зіткненні [12].

$$
F_{c p}=\frac{m_{\kappa} \cdot V_{\kappa}}{\tau}(1+K),
$$

де $F_{c p}$ - середня сила удару (кгс);

$m_{\kappa}$ - маса кулі (кг);

$V_{\kappa}$ - швидкість руху кулі на початку удару (м/сек.);

$\tau$ - час удару (c);

$K$ - коефіцієнт відновлення.

Згідно попередніх досліджень [12-13] відомо, що практичне значення величини коефіцієнта відновлення залежить від твердості поверхні зіткнення для жорсткої поверхні його значення складає 0,56 ; для напівжорсткої поверхні значення складає 0,41 ; для нежорсткої поверхні значення складає 0,22.

Користуючись формулами (3) та (4), при $K=0,41, \tau=0,01$ с., отримали залежність (рис. 2), що зв'язує середню силу удару кулі з дальністю стрільби в межах прямого пострілу для боєприпасів, що розглядаються.

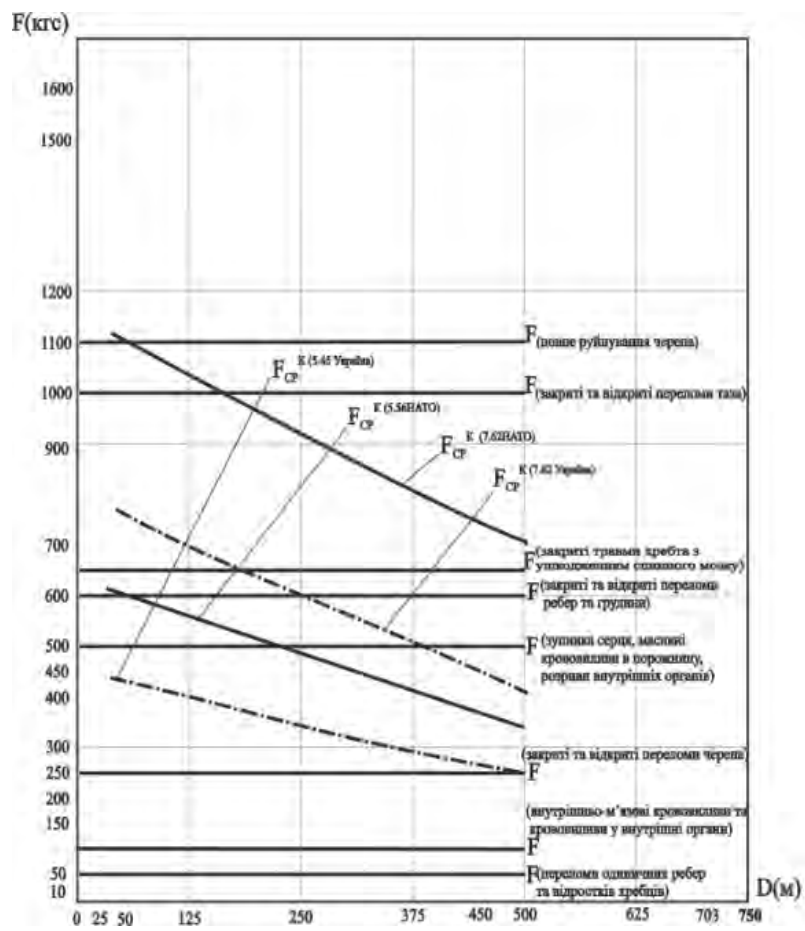

Рис. 2. Залежність середньої сили удару кулі, на відстані стрільби в межах прямого пострілу

та порогові значення сили удару, при яких тіло отримує ЗКТ

Джерело: розроблено авторами за даними [13, C. 20-22].

У [12-13] було визначено експериментально порогові значення сили удару при яких тіло людини отримує ЗКТ різного ступеня тяжкості. 
В (табл. 4) нами було складено та запропоновано для практичного користування класифікацію ЗКТ, яке може мати місце при певній силі удару, визначено ступінь тяжкості, ознаку травмування та втрату боєздатності захищеної цілі.

Таблиця 4

Класифікація ЗКТ за ступеню тяжкості та сила удару

\begin{tabular}{|c|c|c|c|}
\hline $\begin{array}{l}\text { Ступінь } \\
\text { тяжкості }\end{array}$ & $\begin{array}{l}\text { Класифікація ознаки } \\
\text { травмування }\end{array}$ & $\begin{array}{l}\text { Сила } \\
\text { удару } \\
\text { (кгс) }\end{array}$ & Характеристика втрати боєздатності \\
\hline \multirow{2}{*}{$\begin{array}{c}1 \\
\text { легка }\end{array}$} & Садна, синці & $1-3$ & \multirow{2}{*}{$\begin{array}{l}\text { Втрата до 1-3 хв. Обмежена до } 15 \\
\text { хв. Повне відновлення до } 1 \text { доби }\end{array}$} \\
\hline & Обмежені підшкірні гематоми & $15-16$ & \\
\hline \multirow[b]{2}{*}{$\begin{array}{c}2 \\
\text { середня }\end{array}$} & Забійні рани & 20 & \multirow[b]{2}{*}{$\begin{array}{c}\text { Втрата до 3-5 хв. } \\
\text { Обмежена до } 10 \text { діб. } \\
\text { Повне відновлення до 15-20 діб }\end{array}$} \\
\hline & $\begin{array}{c}\text { Внутрішньо-м'язові крововиливи, } \\
\text { поодинокі крововиливи у внутрішні } \\
\text { органи }\end{array}$ & 100 & \\
\hline \multirow{8}{*}{$\begin{array}{c}3 \\
\text { тяжка }\end{array}$} & $\begin{array}{c}\text { Закриті і відкриті переломи: } \\
\text { черепа } \\
\end{array}$ & $250-300$ & \multirow{8}{*}{$\begin{array}{c}\text { Повна втрата до 3-5 хв. } \\
\text { Обмежена до 15-20 діб. } \\
\text { Повне відновлення до 30-60 діб. } \\
\text { Ймовірна смерть }\end{array}$} \\
\hline & повне руйнування черепа & 1100 & \\
\hline & ребер та грудини & $570-700$ & \\
\hline & одиничних ребер & $50-60$ & \\
\hline & $\begin{array}{c}\text { переломи відростків хребців без } \\
\text { пошкодження спинного мозку }\end{array}$ & $50-120$ & \\
\hline & Переломи таза. & $1000-2000$ & \\
\hline & Крововиливи у внутрішні органи & 100 & \\
\hline & $\begin{array}{c}\text { Розриви тканин та внутрішніх } \\
\text { органів } \\
\end{array}$ & $0,15-0,2$ & \\
\hline \multirow[b]{2}{*}{$\begin{array}{c}4 \\
\text { вкрай тяжка } \\
\text { (летальна) }\end{array}$} & $\begin{array}{c}\text { Закриті травми хребта з ушкоджен- } \\
\text { нями спинного мозку }\end{array}$ & $530-762$ & \multirow[b]{2}{*}{$\begin{array}{c}\text { Смерть на місці або внаслідок } \\
\text { ускладнень. } \\
\text { Інвалідність і повна втрата у тих, } \\
\text { хто залишився живим }\end{array}$} \\
\hline & $\begin{array}{c}\text { Зупинка серця, ушкодження великих } \\
\text { кровоносних судин, масивні } \\
\text { крововиливи в порожнину } \\
\text { внутрішніх органів, } \\
\text { розриви і руйнування внутрішніх } \\
\text { органів }\end{array}$ & $500-600$ & \\
\hline
\end{tabular}

Джерело: розроблено авторами.

Порівнюючи отримані значення середньої сили удару кулі з величиною порогового значення сили удару, при якій тіло людини отримує ЗКТ за умовою, що куля влучила в захисну структуру засобу ІБ3, певного класу захисту. В межах відстані стрільби, при яких домінує дія забивного (контузійного) механізму ураження цілі визначимо ступінь тяжкості та час втрати боєздатності захищеної цілі.

Серед досліджуваних боєприпасів, куля $5.45 \times 39$ мм, має значення середньої сили удару на відстані стрільби 300 м близько 330 кгс та швидкість близько 626 м/с, що дає нам вважати про ії здатність нанести травмування 3-ї тяжкої, ступені тяжкості, втрату боєздатності до 20 діб з можливою смертю захищеної цілі за рахунок дії, забивного (контузійного) механізму ураження.

Отримана залежність також вказує на те, що дія забивного (контузійного) механізму ураження цілі спостерігається на всій відстані стрільби зі стрілецької зброї та вносить свій внесок у знищення захищеної цілі.
На основі отриманих енергетичних залежностей куль (рис. 1) визначимо, яким чином буде змінюватись захисний ефект цілі, що знаходиться у засобі ІБ3, класу захисту (Бр.5,4) в залежності від відстані стрільби та типу боєприпасів до стрілецької зброї.

Для цього введемо поняття умовного захисного коефіцієнту цілі, який визначає зв'язок між енергетичним потенціалом засобу ІБЗ і кінетичною енергією кулі за формулою (5).

$$
K_{u}^{3 a x}=\frac{E_{\text {бж }}}{E_{\kappa}},
$$

де $K_{u}^{3 a x}-$ умовний захисний коефіцієнт цілі;

$E_{\text {бж }}-$ порогове значення кінетичної енергії кулі, яку здатний витримати захисний елемент засобу ІБЗ, (Дж);

$E_{\kappa}-$ кінетична енергія кулі у точці зустрічі 3 ціллю (Дж). 
Використовуючи у розрахунках запропоновану формулу (5), отримали залежність (рис. 3), що зв'язує умовний захисний коефіцієнт цілі з дальністю стрільби в межах прямого пострілу для зазначених раніше боєприпасів. 3 рис. 3 видно, що зі збільшенням відстані стрільби з 50 м до 500 м значення $K_{u}^{\text {зах }}$ збільшується з 0,42 до 7,4 .

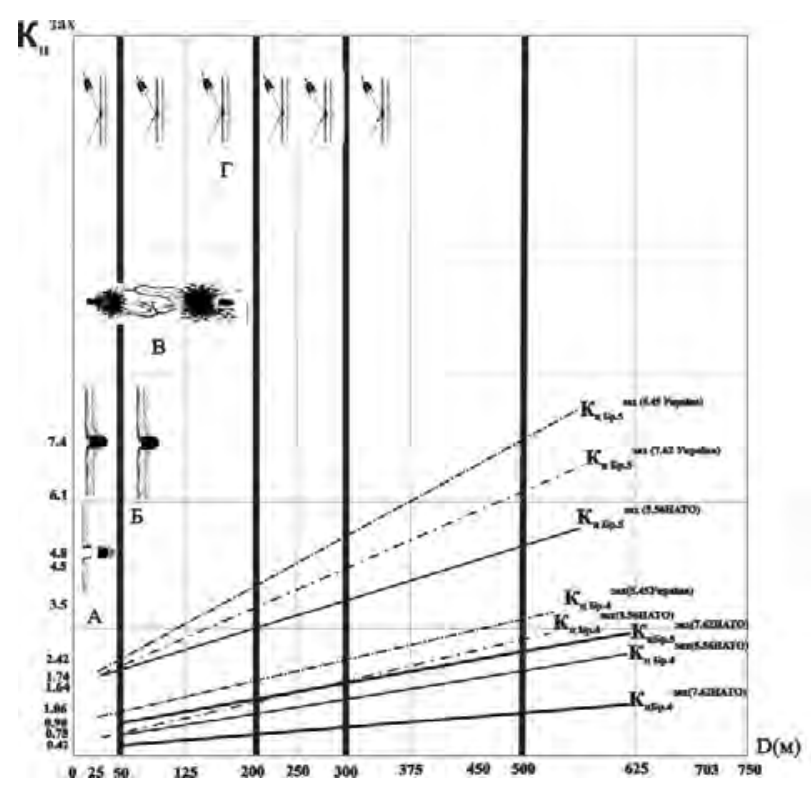

Рис. 3. Залежність умовного захисного коефіцієнту цілі, що знаходиться у засобі ІБЗ класу Бр5,4 на відстані стрільби в межах прямого пострілу

та порогові значення оптимальних відстаней стрільби, при яких мають місце механізми ураження Джерело: розроблено авторами.

У такому разі ми можемо стверджувати, що захисний ефект цілі збільшується зі зростанням відстані за рахунок зменшення уразливої площі цілі та зменшення числа механізмів ураження, які враховуються в сумарній ймовірності ураження цілі.

На відстані стрільби до 50 м за рахунок впливу усіх механізмів ураження: А - пробивного, Б - клиноподібного, В - гідродинамічного (розривний), Гзабивного (контузійний) на ціль $K_{u}^{3 a x}$ має найменші величини, та залежить від енергетичного потенціалу засобу ІБЗ та засобу ураження.

Зменшення енергетичного потенціалу засобу ураження на відстанях стрільби від 50 м до 200 м призводить до зростання $K_{u}^{3 a x}$, за рахунок відсутності пробивного механізму ураження цілі.

На відстанях стрільби від 200 м до 300 м подальше зростання $K_{u}^{3 a x}$ пояснюється втратою засобом ураження клиноподібного та гідродинамічного (розривного) механізмів ураження та домінування забивного (контузійного).

Відстані стрільби від 300 м до 500 м залиша- ються під впливом забивного (контузійного) механізму ураження при якому ціль втрачає боєздатність, для гарантованого знищення цілей на визначених відстанях необхідно підвищувати влучність стрільби у незахищені ділянки цілі за рахунок застосування новітніх прицільних пристосувань. Наявність у цілі засобу ІБ3 класу захисту Бр4,5 зменшує ефективну відстань стрільби зі стрілецької зброї майже в 2 рази. 3 тактико-технічних характеристик автомата Калашникова [14] відомо, що відстань ефективної стрільби по незахищеній цілі є 500 м., а за результатами розрахунків зменшується до $250 \mathrm{м}$.

Таким чином встановлено, що оптимальною дальністю ефективної стрільби за допомогою механічного прицілу зі стрілецької зброї при якій може бути уражена або втратить боєздатність захищена ціль слід вважати до 250 м.

\section{Висновки}

В ході проведеного аналізу:

1. Визначено та введено в тактико-технічні характеристики засобів ІБЗ, показник енергетичного потенціалу $E_{\text {бж}}$.

2. Знайдено залежності кінетичної енергії кулі, на відстані стрільби в межах прямого пострілу та визначено відстані при яких мають місце та домінують певні механізми ураження цілі.

3. Знайдено залежності середньої сили удару кулі, на відстані стрільби в межах прямого пострілу та порогові значення сили удару, при яких тіло отримує ЗКТ.

4. Надано класифікацію ЗКТ, які можуть мати місце при певній силі удару, для визначення ступені тяжкості травмування та мінімального часу на відновлення боєздатності ураженої цілі.

5. Визначено поняття умовного захисного коефіцієнту цілі та знайдено його залежність від відстані стрільби в межах прямого пострілу.

6. Встановлено оптимальну відстань ефективної стрільби, при якій має місце ураження або втрата боєздатності захищена ціль.

Виходячи 3 проведеного аналізу механізмів ураження можна надати практичні рекомендації щодо виведення $з$ ладу живої сили супротивника, що оснащений ІБЗ виробництва РФ (враховуючи, що найбільш розповсюдженим класом бронежилетів є Бр4):

- при веденні бойових дій в умовах населеного пункту (тобто в умовах ближнього бою на відстанях до 100 м.) 3 застосуванням стрілецької зброї калібру 5,45, 5,56 мм. рекомендується встановлення прицілу “1”, режим ведення вогню - короткими чергами;

- при веденні позиційних бойових дій, для стрілецької зброї калібру 5,45, 5,56 мм. в (табл. 5) складено та рекомендовано вихідні установки для стрільби (табл. 5). 
Таблиця 5

Вихідні установки для стрільби

\begin{tabular}{|c|l|}
\hline Відстань & \multicolumn{1}{|c|}{ Рекомендація } \\
\hline \multirow{2}{*}{300 м. } & $\begin{array}{l}\text { Приціл “П”, режим ведення вогню - } \\
\text { короткими чергами, точка } \\
\text { прицілювання - нижче середини цілі }\end{array}$ \\
\hline $300-500$ м. & $\begin{array}{l}\text { Приціл відповідно до відстані, } \\
\text { режим ведення вогню - короткими } \\
\text { чергами, точка прицілювання - } \\
\text { незахищені ділянки цілі }\end{array}$ \\
\hline більше & $\begin{array}{l}\text { Обстріл цілі не ефективний. Перехід } \\
\text { на застосування зброї калібру } \\
\text { 7,62 мм. та вище }\end{array}$ \\
\hline
\end{tabular}

Джерело: розроблено авторами.
Подальшим напрямком дослідження може бути оцінка впливу засобів ІБЗ на ефективність стрільби зі стрілецької зброї, її основних показників: ймовірності ураження цілі та середньої витрати боєприпасів на знищення цілі в умовах застосування противником засобів ІБЗ.

\section{Список літератури}

1. Юрова Т. Бронежилети та розвантажувальні системи в бойовому екіпіруванні солдата Армії оборони Ізраілю XX - XXI ст. / Т. Юрова // Військово-історичний меридіан. - 2016. - № 2(12). - С. 72-85. - Режим доступу: https://vim.gov.ua/pages/_journal_files/09.07.2016/pdf/full.pdf.

2. Куриляк В.В. Оцінка якості матеріалів бронежилетів в умовах ударних навантажень / В.В. Куриляк, О.М. Хорошилов // Молодий вчений. - 2018. - № 7(59). - С. 299-302.

3. Марченко О.С. Перспективи розвитку засобів індивідуального бронезахисту / О.С. Марченко // Сучасна спеціальна техніка. - 2014. - № 3(38). - С. 99-106.

4. Баулин Д. Индивидуальные средства бронезащиты: вопросы требований и класификации / Д. Баулин, С. Горелышев, С. Манжура // Збірник наукових праць Національної академії Державної прикордонної служби України. - 2016. - № 3(69). - С. 210-224.

5. Данилин Г.А. Основы проектирования патронов к стрелковому оружию / Г.А. Данилин, В.П. Огородников, А.Б. Заволокин. - СПб.: БГТУ, 2005. - 374 с.

6. Біленко О.І. Методика зниження енергії віддачі стрілецької зброї для сил безпеки / О.І. Біленко, К.В. Першина, Д.В. Павлов // Наука і техніка Повітряних Сил Збройних Сил України. - 2017. - № 4(29). - С. 110-115.

7. Біленко О.І. Методика зниження енергетичних характеристик поражаючого елементу після відбиття від перешкоди / О.І. Біленко, О.О. Кириченко, Д.В. Павлов // Технічні науки. - 2018. - № 4(45). - С. 14-18.

8. ГОСТ Р 50744 - 95. Бронеодежда. Классификация и общие технические требования. - М.: Издательство стандартов, 2016. - $11 \mathrm{c}$.

9. Розробка рекомендацій щодо підвищення рівня індивідуальної безпеки особового складу піротехнічних підрозділів при вилученні, транспортуванні та знищенні вибухонебезпечних предметів: звіт про НДР:15-18 / Національний університет цивільного захисту України; кер. Васильченко О.І.; викон. Стецюк Є.І. - Х., 2015. - 99 с. - № ДР 0114U002245. - Інв. № 332 .

10. Мішалов В.Д. Судова медицина / В.Д. Мішалов, Т.В. Хохолєва, В.Т. Бачинський. - Ч.: Місто, 2018. - 574 с.

11. Семиколенов Н.П. Основы стрельбы из оружия стрелковых подразделений / Н.П. Семиколенов, Ф.Г. Бондаренко, Н.Я. Краснер. - М.: ВИ МО СССР, 1958. - 266 с.

12. Громов А.П. Биомеханика травмы: повреждения головы, позвоночника и грудной клетки / А.П. Громов. - М.: Медицина, 1979. - 275 с.

13. Молин Ю.А. Судебно-медицинская оценка силы тупой травмы, вызывающей механические повреждения / Ю.А. Молин. - СПб.: МАПО, 2003. - 21 с.

14. Настанова зі стрілецької справи. 5,45-мм автомати Калашникова (АК-74, АКС-74, АК-74Н, АКС-74Н) та 5,45мм ручні кулемети Калашникова (РПК-74, РПКС-74, РПК-74Н,РПКС-74Н), - К.: Варта, 2005. - 120 с.

\section{Відомості про авторів:}

\author{
Лисиця Андрій Вікторович \\ викладач \\ Харківського національного університету \\ Повітряних Сил ім. І. Кожедуба, \\ Харків, Україна \\ https://orcid.org/0000-0002-6632-4770
}

\section{Information about the authors:}

\author{
Andrii Lysytsia \\ Instructor \\ of Ivan Kozhedub Kharkiv \\ National Air Force University, \\ Kharkiv, Ukraine \\ https://orcid.org/0000-0002-6632-4770
}


Тіхонов Іван Митрофанович кандидат військових наук доцент заступник начальника кафедри Харківського національного університету Повітряних Сил ім. І. Кожедуба, Харків, Україна https://orcid.org/0000-0002-6747-015X

Василенко Віталій Віталійович старший викладач

Харківського національного університету Повітряних Сил ім. І. Кожедуба,

Харків, Україна

https://orcid.org/0000-0002-3577-7421

\section{Явтушенко Володимир Олексійович} старший викладач

Харківського національного університету

Повітряних Сил ім. І. Кожедуба,

Харків, Україна

https://orcid.org/0000-0003-2915-0427

\author{
Ivan Tikhonov \\ Candidate of Military Sciences Associate Professor \\ Deputy Head \\ of Ivan Kozhedub Kharkiv \\ National Air Force University, \\ Kharkiv, Ukraine \\ https://orcid.org/0000-0002-6747-015X
}

\author{
Vitaliy Vasilenko \\ Senior Instructor \\ of Ivan Kozhedub Kharkiv \\ National Air Force University, \\ Kharkiv, Ukraine \\ https://orcid.org/0000-0002-3577-7421
}

\author{
Vladimir Yavtushenko \\ Senior Instructor \\ of Ivan Kozhedub Kharkiv \\ National Air Force University, \\ Kharkiv, Ukraine \\ https://orcid.org/0000-0003-2915-0427
}

\title{
АНАЛИЗ МЕХАНИЗМОВ ПОРАЖЕНИЯ ЦЕЛИ, ОСНАЩЕННОЙ СРЕДСТВАМИ ИНДИВИДУАЛЬНОЙ БРОНИРОВАННОЙ ЗАЩИТЫ ИЗ СТРЕЛКОВОГО ОРУЖИЯ НА ОСНОВЕ ЭНЕРГЕТИЧЕСКОГО ПОТЕНЦИАЛА И СИЛЫ УДАРА ПУЛИ 5,45 мм, 5,56 мм, 7,62 мм
}

\author{
А.В. Лисица, И.М. Тихонов, В.В. Василенко, В.А. Явтушенко
}

В статье проведен анализ защитных свойств средств индивидуальной бронированной зашиты. Исследуется изменение защитного эффекта в зависимости от типа патрона на дальности стрельбы, не превыщающего дальность прямого выстрела. Рассмотрена зависимость кинетической энергии и средней силы удара пули от дальности стрельбы, влияние пробивного, клиноподобного, гидродинамического и забойного эффекта пуль разного калибра. Оиенень известные поражения цели, определено доминирование механизмов поражения в зависимости от дальности стрельбы. Предложено для практического использования классификацию заброневого контузионного травмирования, которое возникает при определённой силе удара, для определения минимального времени на восстановление боеспособности пораженной иели. Результаты роботы могут быть использованы при формировании требований к правилам стрельбы по защищенным целям, а также при обучении стрельбе из стрелкового оружия.

Ключевые слова: средство индивидуальной бронированной защиты, прямой выстрел, кинетическая энергия пули, средняя сила удара пули, защитный коэффициент цели, механизм поражения цели.

\section{WOUNDING MECHANISM ANALYSIS OF TARGET WHICH HAS INDIVIDUAL BODY ARMOURED FACILITIES OF SMALL ARMS WEAPONS ON BASIS OF ENERGY POTENTIAL AND IMPACT FORCE OF BULLETS $5,45 \mathrm{~mm}, 5,56 \mathrm{~mm}, 7,52 \mathrm{~mm}$}

A. Lisitsya, I. Tikhonov, V. Vasilenko, V. Yavtushenko

It's analysed the protective properties of individual armoured defence in the article. A change in the protective effect in accordance with the type of cartridge of the firing range within the direct shot are examined. The occurrence of after armoured contusion, hydrodynamic shock and the conditions they take place at are considered. A review of the dependence of kinetic energy and medium-force of bullet impact on the firing range are given. The conclusion of the impact of penetrative, wedge-shaped, hydrodynamic and the striking ability of bullets of different calibers is made. The relevance of defeating of armoured target of the opponent under battlefield conditions are considered. The interdependence of energetic and power characteristics of native and foreign ordinary bullets on the range of small arms firing in direct firing in order to search optimal effective range of armoured targets is investigated. The known dependence of external ballistics has been used. The known damage causes of target defeat have been evaluated. It is determined at which range of firing the one or another cause dominates. The classification of after armoured contusion which takes place in definite impact force to identify the minimal time of readiness recovery of the destroyed target are listed for practical use. For the practical use of concept conditional protective to the target coefficient. His change is investigational depending on the class of defence of means of individual defence, as to ammunition and distance of firing. Initial options are made for firing from small-arms for that have facilities of defence: aims breech-sight, aiming point, distance of firing. The results of the work that's been completed can be used in the formation of requirements for the rules of shooting the armoured target and in teaching the shooting as well.

Keywords: means of individual armoured protection, direct shooting, kinetic energy of bullet, average force of punch, after armoured contusion, penetrative, wedge-shaped, hydrodynamic (explosive), striking cause of destroyed target. 